\title{
STUDIES ON WHITE PINE BLISTER RUST IN NOVA SCOTIA ${ }^{1}$
}

\author{
By W. K. MCGINN 2 and A. G. DAVIDSON 3
}

\author{
W. K. McGINN
}

W. K. McGinn received the degree of Bachelor of Science in Forestry at the University of Toronto in 1950. He bad worked on different fields of forestry as an undergraduate and in 1949 spent the summer as an assistant at the Laboratory of Forest Patbology in Toronto. In 1950 be was transferred to the Laboratory of Forest Pathology in Fredericton and worked mainly on white pine blister rust until early 1953 when be enlisted in the R.C.A.F. as a Flying Officer.

\section{A. G. DAVIDSON}

Alexander Grant Davidson received a Bachelor of Science in Forestry from the University of New Brunswick in 1948. In 1951 be received a Master of Arts from the University of Toronto, bis thesis being entitled, "Decay of Balsam Fir (Abies balsamea L. MILL.) in the Green River Watershed of New Brilnswick."

He was employed on forest inventory work during summer seasons by the New Brunswick Forest Service until May 1947, when be joined the staff of the Laboratory of Forest Pathology. He has worked bere each summer until May, 1951, when be was appointed to a permanent position as an Agricultural Research Officer.

\section{ABSTRACT}

Studies were undertaken in Nova Scotia to determine (i) the effect of different cutting practices on the esiablishment of a RiBes population and of white pine regeneration, (ii) whether blister rust is a major factor in retarding the establisbment of white pine regeneration, and (iii) the feasibility and cost of RIBEs eradication as a direct control measure against blister rust. No relationsbip was found to exist between RIBEs establisbment and the degree of cutting. Uncut softwood stands, where white pine is the predominant species, show evidence of producing a future pine crop. Forest types supporting white pine appear to offer the best opportunities for pine reproduction where a clearcutting operation bas given the stand maximum opening. Results of the present study to date do not show that blister rust is a major factor in retarding the establishment of white pine regeneration. To eradicate RiBEs from the study area by a complete systematic search required 1 man-bour per acre. Because of the small number of RrBes plants found and of the tendency for them to occur consistently in moist, low-lying habitats, a complete systematic search for these plants appears to be unnecessary. It is suggested that one man, trained to recognize RIBEs and their probable location, could cover large forest tracts with a minimum of time expended in searcbing localities unlikely to support these plants.

Contribution No. 99 from Division of Forest Biology, Science Service, Department of Agriculture, Ottawa.

2 Formerly Technical Officer, now in the Royal Canadian Air Force. wick.

3 Agricultural Research Officer Laboratory of Forest Pathology, Fredericton, New Bruns- 


\section{INTRODUCTION}

Eastern white pine, Pinus strobus L., is highly susceptible to white pine blister rust, Cronartium ribicola Fischer, a disease caused by a fungus introduced from Europe. Although this pathogen has by no means reached epidemic proportions, it is none the less regularly present in white pine stands throughout New Brunswick and Nova Scotia.

In 1952, investigations were begun in Nova Scotia to determine (I) the effect of different cutting practices on the establishment of a Ribes (currants and gooseberries, the alternate hosts of the white pine blister rust fungus) population and of white pine regeneration, (II) whether blister rust is a major factor in retarding the establishment of white pine regeneration, and (III) the feasibility and cost of Ribes eradication as a direct control measure against blister rust.

Complete co-operation was obtained from the Mersey Paper Company, Liverpool, Nova Scotia, which made available its limits within Nova Scotia and supplied the labor used in the eradication.

\section{STUDY AREA}

Blanket Hill, in the vicinity of Dalhousie Lake, Annapolis County, was selected as the study area because it embodies a majority of typical white pine stands found throughout the southwestern part of the Province. Within the limits under examination, the white pine stands have been either clear cut, selection cut, or undisturbed. In addition, there are hardwood, mixed, and softwood stands; numerous black spruce swamps; and wastelands containing alder swale or muskeg.

\section{Plot Establishment and Examination}

\section{FIELD METHODS}

Local control of the blister rust fungus may be accomplished by destroying the Ribes within 900 feet of the white pine (2). The cultivated European black currant (Ribes nigrum L.), which is very susceptible to the rust, should be destroyed within 1 mile of white pine (1). However, none of these were present in the study area. As a preliminary to the eradication, a rectangular plot ( $40 \times 50$ chains) containing 200 acres to be protected was defined within the study area. This was surrounded by a buffer strip of 990 feet ( 15 chains). If the Ribes were then eradicated from the plot and buffer strip (a total of 560 acres), the plot would be free from further infection owing to the surrounding 990-foot protective strip.

Then permanent, half-acre, circular plots, five within the eradication area and five outside, were established for determining the amount of Ribes and white pine establishment, as well as to follow future blister infection. The five outside plots were located in stands similar to those occupied by the plots within the protected area. Following a description of the sample plot types, the symbols used being those of the Mersey Paper Company.

Sy-CO: Plots 1 and 6

Young softwood stands, $45-60$ years old, mainly spruce and balsam fir. Mature pine clear cut in 1948. 


\section{$M y(P):$ Plots 2 and 7}

Young mixed softwood-hardwood stand $40-60$ years old. Balsam fir, pine, spruce, birch, and maple. A selection cut for white pine made in 1948.

\section{$P$ : Plots 3 and 8}

Predominately white pine with scattered birch, balsam fir, spruce and maple. A selection cut for white pine made in 1946.

\section{$S y(P)$ : Plots 4 and 9}

Mixed softwoods, predominantly white pine 60-70 years of age. No cutting has been done in these areas.

\section{Sy $(P)$ : Plots 5 and 10}

Mixed softwoods, approximately 50 per cent white pine, 50 per cent spruce. A selection cut for white pine made in 1948.

All white pine ( 3 inches in diameter and above) in these sample plots were tagged and classified according to the degree of rust infection as follows:

0-tree with no blister rust

1 - tree with a stem canker

2-tree with a branch canker

3-tree with a fatal branch canker, i.e., a branch canker that appeared certain to grow into the stem

4 -tree dead due to blister rust

In addition, information was obtained on the amount of white pine regeneration and on the occurrence of blister rust on this regeneration.

\section{Eradication of Ribes}

Although it seemed improbable that Ribes would become established on certain sites, i.e., in dense young softwood stands or on well-stocked hardwood ridges, a scheme of systematic coverage of the entire 560 acres was adopted. This was necessary if the cost of eradicating ribes from this area of known acreage was to be determined.

To accomplish the eradication, a crew of six men was employed. One man divided the area into parallel strips, one chain to one and one-half chains in width, marking the boundaries with string. Plot boundaries, survey lines, roads, and streams were used as tie-ins whenever possible. Four men followed, doing the eradication, while the fifth man acted as foreman, observing the spacing of the men and checking for missed Ribes.

The general procedure was to eradicate from one strip at a time. The four men eradicating moved along the strip in a staggered formation, each man covering one-quarter of the width of the strip and keeping 2 to 3 feet behind the next man. This arrangement allowed each worker to see the next one to him and assured a more complete coverage of the strip. When the Ribes occurred in patches, the men converged and after the plants were removed, crew formation was re-established.

Each crewman was equipped with a stout stick or cane. This was used for parting or bending back the undergrowth, where necessary, to expose hidden 
bushes. The Ribes bushes were removed by hand and upon being uprooted, the soil was shaken from the roots and the plants were hung in a crotch of a small tree (other than white pine), or placed on a bare rock or stump and covered with a stone to prevent blowing away. A record was kept of the kind, number, and location of Ribes species eradicated.

\section{Discussion AND Results}

The occurrence of white pine blister rust and white pine regeneration in the stand types is given in Table I. The values obtained from the two plots in each type have been combined to give results on a per acre basis. Approximately 3 per cent of the white pine were suffering from active blister rust stem or branch cankers, but no mortality directly attributable to the fungus was noted. This low degree of infection is directly related to the small number of Ribes found in the area, i.e., an average of half a plant per acre (Table II).

TABLE I

Occurrence of White Pine Blister Rust and

White Pine Regeneration on Permanent Sample Plots

\begin{tabular}{|c|c|c|c|c|c|c|c|c|}
\hline \multirow{2}{*}{$\begin{array}{l}\text { Forest } \\
\text { type }\end{array}$} & \multirow{2}{*}{$\begin{array}{l}\begin{array}{l}\text { Type of } \\
\text { cutting }\end{array} \\
\text { Clear }\end{array}$} & \multirow{2}{*}{$\begin{array}{c}\begin{array}{c}\text { Total living } \\
\text { white pine } \\
\text { per acre }\end{array} \\
66\end{array}$} & \multicolumn{5}{|c|}{$\begin{array}{l}\text { Degree of blister } \\
\text { rust infection } \\
\text { per acre }\end{array}$} & \multirow{2}{*}{$\begin{array}{c}\begin{array}{c}\text { White pine } \\
\text { regeneration } \\
\text { per acre }\end{array} \\
5400\end{array}$} \\
\hline & & & 64 & 1 & 1 & - & - & \\
\hline $\mathrm{My}(\mathrm{P})$ & Selection & 98 & 96 & 2 & - & - & - & 600 \\
\hline $\mathrm{P}$ & Selection & 123 & 119 & 2 & 2 & - & - & 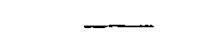 \\
\hline $\operatorname{Sy}(\mathrm{P})$ & Nil & 175 & 168 & 6 & 1 & - & - & 2400 \\
\hline \multirow[t]{2}{*}{ Sy(P) } & Selection & 83 & 81 & - & 2 & - & - & - \\
\hline & & 545 & 528 & $11 *$ & $6^{*}$ & $\ldots$ & - & - \\
\hline
\end{tabular}

-White pine infected by blister rust $3.1 \%$.

* Estimated by detailed examination of four $6 \mathrm{ft}$. $\times 6 \mathrm{ft}$. plots in each type.

TABLE II

Occurrence and Condition of Ribes Eradicated

\begin{tabular}{|c|c|c|c|}
\hline Species & Total & $\begin{array}{l}\text { Number infected } \\
\text { by blister rust }\end{array}$ & Habitat \\
\hline R. glandulosum Grauer & 156 & 56 & \multirow{3}{*}{$\begin{array}{l}\text { Low alluvial } \\
\text { ground or dense } \\
\text { sphagnous thickets }\end{array}$} \\
\hline R. birtellum Michx. & 41 & 24 & \\
\hline R. sativum Syme & 44 & 1 & \\
\hline Total & 241 & 81 & Roch outcropping \\
\hline Average per acre & 0.4 & 0.1 & \\
\hline
\end{tabular}

Although in some districts there may be a relationship between Ribes establishment and the degree of cutting that has taken place, it seems quite evi- 
dent that there is no such relationship in Nova Scotia. Throughout Nova Scotia almost all uncultivated Ribes species prefer rich low woods, swamps, or open rocky ground (3), none of which are particularly favorable white pine sites. On the entire 560-acre eradication block, Ribes, with only one exception, were located in low alluvial ground and in dense sphagnous thickets. The exception was a clump of plants growing on top of a rock outcropping. Table II contains a summary of the occurrence and condition of the Ribes species eradicated. One section of over ten acres, cut five years ago and having nothing beyond an occasional birch and balsam fir still standing, failed to yield, despite a most diligent search, even one Ribes plant.

White pine regeneration in the stand types shows a definite trend as indicated in Table I. Of the logged areas, only those subject to clear cutting have succeeded in re-establishing, to any appreciable degree, a future stand of white pine. Uncut softwood stands, where white pine is the predominant species, show evidence of producing a future pine crop. Forest types supporting white pine appear to offer the best opportunities for pine reproduction where a clear cut operation has given the stand maximum opening.

The results of the present study to date do not show that blister rust is a major factor in retarding the establishment of white pine regeneration. Only 11 diseased seedlings ( 2 years old and younger) were found on the entire 10 plots. These were located in one group near a small marshy tract, harboring several infected swamp currants.

To eradicate the Ribes from the study area required 561 man-hours or approximately 1 man-hour per acre. From the experience gained by the eradication of Ribes in the present study, it can be said that complete coverage by the strip method with a full crew (five or six men) is a time-consuming and unwarranted procedure in Nova Scotia. This conclusion is based on the small number of Ribes plants found in the study area and on the tendency for Ribes to occur consistently in moist, low-lying habitats, making the complete systematic coverage of the area unnecessary. Since the Blanket Hill area consists of typical white pine country, it is felt that the conclusions drawn from this study may well be applied to a considerable portion of the white pine regions throughout Nova Scotia.

In any future Ribes eradication in Nova Scotia, a method of eradication more suitable to the district should be used. It is suggested that one man, trained to recognize Ribes and their probable location, thoroughly scout the area under consideration. Those places where Ribes are most likely to be found, such as swamps, stream courses, roadways, areas of blowdown, and old pastures, should be examined carefully. Other localities that yield no Ribes after two hours of searching (an arbitrary time limit that can be lessened ur extended depending on the size of the aren) could be considered as innocuous to neighboring white pine. If the population of Ribes is light, they can be eradicated by the scout. Large patches of skunk currants and gooseberries should, however, be plotted on a map or more preferably, on aerial photographs, and eradicated later by crews of two to four men. In 
this manner, large forest tracts could be covered with a minimum of time expended in searching localities unlikely to support Ribes.

\section{ACKNOWLEDGMENTS}

The authors wish to express their sincere gratitude to Mr. D. R. Redmond, Officer-in-Charge, Laboratory of Forest Pathology, Fredericton, N.B. for suggestions and advice given during the course of the study; and to Mr. R. S. Johnson, Chief Forester, and other members of the Mersey Paper Company, for their assistance in carrying out the study.

\section{REFERENCES}

1. DETWILER, S. B. Black currant spreads white pine blister rust. U, S. Dept. Agr. Misc Pub. 27:1-8, 1930 .

2. POSEY, G. B. and C. R. FORD. Survey of blister rust infection on pines at Kitterg Point, Maine, and the effect of Ribes eradication in controlling the disease. Jour. Agr. Res. 28: 1253-1258. 1924.

3. ROLAND, A. E. The flora of Nora Scotia. Proc. N. S. Inst. Sci. 21, Part 3: 95-642. $1944-45$. 